\title{
PEMBELAJARAN BAHASA INGGRIS PADA ANAK USIA DINI DI KEC SUKOLILO SURABAYA
}

\author{
Andini Dwi Arumsari \\ Bustomi Arifin \\ Zulidyana Dwi Rusnalasari \\ Universitas NAROTAMA Surabaya \\ email: Andini.dwi@narotama.ac.id
}

\begin{abstract}
Abstrak: Pembelajaran Bahasa Inggris Pada Anak Usia Dini Di Kecamatan Sukolilo Kota
Surabaya Bahasa inggris telah digunakan sebagai bahasa komunikasi sejak PAUD. Tuntutan tersebut membuat orang tua berlomba-lomba memasukkan anak mereka ke sekolah yang menggunakan bahasa inggris sebagai media bahasa dalam pembelajaran. Pembelajaran bahasa inggris sebagai bahasa asing di Indonesia pun mulai merambah jenjang PAUD. Anak yang berusia 0 - 6 tahun yang merupakan masa keemasan (golden age) dan merupakan masa kritis dalam tahapan kehidupan manusia yang akan menentukan perkembangan anak selanjutnya. Semua aspek dalam penggunaan bahasa sebaiknya diperkenalkan kepada anak sebelum masa keemasan ini berakhir. Bahasa inggris pada AUD sudah mulai diperkenalkan pada jenjang TK. Dalam pembelajaran bahasa inggris membutuhkan metode pembelajaran yang tepat untuk meningkatkan minat dan keinginan siswa dalam menggunakan bahasa inggris dalam aktifitas belajar yang menyenangkan dan diminati siswa, baik lisan maupun tulisan secara lancar dan sesuai dengan konteks sosialnya. Penelitian ini berupaya memperoleh pengetahuan mengenai PAUD yang berkaitan dengan pembelajaran Bahasa Inggris jenjang pendidikan TK di Kecamatan Sukolilo Kota Surabaya. Teknik pengumpulan data dilakukan dengan wawancara untuk memperoleh informasi verbal secara langsung. Dari jumlah total 57 TK yang ada di kecamatan Sukolilo, ada 28 TK yang menjadi tempat penelitian. Dari data yang didapat, sebanyak 28 TK yang menjadi subyek penelitian telah memberikan pembelajaran bahasa inggris selama proses belajar mengajar.
\end{abstract}

Kata kunci: Pembelajaran, Bahasa Inggris, Anak Usia Dini.

\begin{abstract}
English Lesson Learning On Children Age In Sukolilo Kota Surabaya Sub Distric English has been used as a language of communication since early childhood. These demands make parents vying to include their children to schools that use English as a medium of language in learning. Learning English as a foreign language in Indonesia began to reach the level of early childhood education. Children aged 0-6 years which is a golden age (golden age) and is a critical period in the stage of human life that will determine the development of the next child. All aspects of language use should be introduced to the child before this golden age ends. English on the AUD has begun to be introduced at the kindergarten level. In learning English requires appropriate learning methods to increase interest and desire of students in using English in learning activities that are fun and interested students, both oral and written fluently and in accordance with its social context. This research seeks to gain knowledge about early childhood education related to English language learning in kindergarten education in Sukolilo sub-district of Surabaya city. Data collection techniques were conducted by interviews to obtain verbal information directly. From the total number of 57 kindergartens in Sukolilo sub-district, there are 28 kindergarten that become the research place. From the data obtained, as many as 28 kindergarten who became the subject of research has provided learning English during the learning proces.
\end{abstract}

Keywords: Learning, English, Early Childhood. 
Saat ini, sudah menjadi hal yang umum masyarakat bisa menggunakan bahasa inggris. Bahasa Inggris merupakan bahasa internasional mempunyai peranan penting dalam kehidupan sehari-hari setiap orang di seluruh dunia. Bahasa Inggris biasa digunakan dalam pendidikan, pekerjaan, hiburan, komunikasi elektronik, dan perjalanan, dan menjadikan Bahasa Inggris sangat penting untuk dikuasai. Artinya, masyarakat yang berasal dari beragam latar belakang daerah asal, agama dan budaya telah memiliki suatu media yang disepakati untuk berkomunikasi satu sama lainnya, yaitu Bahasa Inggris.

Untuk itu, kita sebaiknya bisa menggunakan bahasa inggris dengan baik, baik secara lisan dan tulisan. Bahasa menjadi alat komunikasi yang sangat penting untuk berkomunikasi. Bahasa inggris pun telah digunakan sebagai bahasa komunikasi sejak usia dini. Tuntutan tersebut membuat para orang tua berlomba-lomba memasukkan anak mereka ke sekolah yang menggunakan bahasa inggris sebagai media bahasa dalam pembelajaran. Akhir-akhir ini, pembelajaran bahasa inggris sebagai bahasa asing di Indonesia mulai merambah jenjang pendidikan anak usia dini (Sulistyo, 2009).

Sesuai dengan UU No 20 tahun 2003 tentang Sistem Pendidikan Nasional, Bab 1, Pasal 1, Butir 14, Pendidikan Anak Usia Dini (PAUD) adalah suatu upaya pembinaan yang ditujukan kepada anak sejak lahir sampai dengan usia 6 tahun melalui pemberian rangsangan pendidikan untuk membantu pertumbuhan dan perkembangan jasmani dan rohani agar anak memiliki kesiapan dalam memasuki pendidikan lebih lanjut.

Pasal 28 tentang Pendidikan Anak Usia Dini menyatakan bahwa: (1) PAUD diselenggarakan sebelum jenjang Pendidikan Dasar, (2) PAUD dapat diselenggarakan melalui jalur pendidikan formal, non formal dan/atau informal, (3) PAUD jalur pendidikan formal: TK, RA atau bentuk lain yang sederajat, (4) PAUD jalur pendidikan non formal: KB, TPA, atau bentuk lain yang sederajat, dan (5) PAUD jalur pendidikan informal: pendidikan keluarga atau pendidikan yang diselenggarakan oleh lingkungan. Data yang didapat oleh Depdiknas tahun 2002, baru $28 \%$ dari 26,1 juta anak usia 06 tahun yang mendapat pendidikan usia dini.

Anak usia dini adalah anak yang berusia $0-6$ tahun. Menurut para ahli, usia sebelum memasuki usia dasar merupakan masa keemasan (golden age) dan merupakan masa kritis dalam tahapan kehidupan manusia yang akan menentukan perkembangan anak selanjutnya. Semua aspek dalam penggunaan bahasa sebaiknya diperkenalkan kepada anak sebelum masa keemasan ini berakhir. Pada usia ini, sangat penting untuk diperkenalkan cara berbahasa yang baik dan benar karena dengan penggunaan bahasa yang baik dan benar ini sangat berguna untuk berkomunikasi dengan lingkungannya.

Perkembangan bahasa anak sebenarnya sudah dimulai sejak anak lahir dengan menggunakan bahasa atau prawicara yang paling sederhana yaitu "menangis", kemudian perkembangan dalam bentuk "celoteh/ocehan", kata/ kalimat sederhana disertai gerakan tubuh/ syarat sebagai pelengkap bicara. Dalam psikologi pendidikan dikenal adanya teori pembelajaran yang dapat digunakan sebagai landasan pengajaran.

Taman kanak-kanak adalah salah satu lembaga yang bertugas untuk membantu tumbuh kembang anak usia dini. Untuk mewujudkan hal tersebut Taman Kanak-kanak mempunyai fungsi sebagai pengembang berbagai potensi yang dimiliki oleh anak. Potensi tersebut meliputi kemampuan kognitif, bahasa, jasmani (motorik kasar dan halus), dan sosial emosional. Pendidikan Anak Usia Dini (PAUD) merupakan institusi prasekolah yang mengenalkan bentuk dan budaya sekolah.

Pemberian bahasa inggris pada anak pra-TK atau TK ini sangat menggembirakan, tetapi di sisi lain mulai muncul kekhawatiran 
karena disinyalir masih banyak kekurangan dalam hal metode dan materi yang sesuai yang akan diberikan kepada anak usia dini. Terlebih lagi secara teknis, dalam pelaksanaannya peranan guru dan kebijakan masing-masing sekolah menentukan bagaimana pembelajaran Bahasa Inggris sebagai bahasa asing untuk anak pra-TK atau TK tersebut terselenggara.

Taman Kanak-kanak (TK) adalah salah satu bentuk satuan pendidikan anak usia dini pada jalur formal yang diselenggarakan program pendidikan bagi anak usia empat sampai enam tahun. Taman kanak-kanak merupakan salah satu lembaga yang bertanggung jawab untuk membantu tumbuh kembang anak usia dini. Untuk mewujudkan hal tersebut Taman Kanak-kanak mempunyai fungsi untuk mengembangkan berbagai potensi yang dimiliki oleh anak usia dini. Potensi tersebut meliputi ranah kognitif, bahasa jasmani (motorik kasar dan halus), dan sosial emosional.

Masa paling sensitif perkembangan bahasa dalam kehidupan seseorang adalah antara umur dua sampai tujuh tahun. Semua aspek dalam berbahasa harus diperkenalkan pada anak sebelum masa sensitif ini berakhir. Di masa ini sangat penting diperkenalkan cara berbahasa yang baik dan benar, karena keahlian ini sangat berguna untuk berkomunikasi dengan lingkungannya.

Bahasa adalah suatu sistem simbol yang digunakan untuk berkomunikasi dengan orang lain. Pada manusia, bahasa ditandai oleh kemampuan individu untuk menciptakan kalimat bermakna yang tidak pernah berhenti dengan menggunakan seperangkat kata dan aturan terbatas, yang menjadikan bahasa sebagai upaya yang sangat kreatif.

Menurut Santrock (2004), bahasa terdiri dari bunyi-bunyian dasar atau fonem. Di dalam bahasa inggris terdapat 36 fonem. Fonologi (phonology) adalah studi tentang sistem bunyi-bunyian bahasa. Ketentuanketentuan fonologis menjamin bahwa urutan bunyi tertentu terjadi (misalnya sp, ba, atau ar) dan yang lain tidak terjadi (misalnya $\mathrm{zx}$ atau qp). Satu contoh fonem yang baik dalam bahasa inggris adalah $/ \mathrm{k} /$, yakni bunyi yang ditentukan oleh kuruf $k$ dalam kata ski dan huruf $c$ dalam kata cat. Walaupun bunyi $/ \mathrm{k} /$ sedikit berbeda dalam kedua kata ini, variasinya tidak dibedakan, dan bunyi $/ \mathrm{k} /$ digambarkan sebagai fonem tunggal. Dalam beberapa bahasa, seperti bahasa Arab, jenis variasi mewakili fonem yang terpisah.

Morfology (morphology) mengacu kepada ketentuan-ketentuan pengkombinasian morfem. Morfem adalah rangkaian bunyibunyian terkecil yang memberi makna kepada apa yang kita ucapkan dan dengar. Setiap kata dalam bahasa inggris terdiri dari satu atau lebih morfem. Beberapa kata yang terdiri dari satu morfem tunggal (misalnya help), sementara kata yang lain terdiri dari lebih dari satu morfem (misalnya helper memiliki dua morfem, help + er, dimana morfem er berarti "orang yang menolong").

Sintaksis (syntax) melibatkan bagaimana kata-kata dikombinasikan untuk membentuk ungkapan dan kalimat yang dapat diterima. Suatu konsep yang berkaitan erat dengan sintaksis adalah tata bahasa (grammar), yaitu gambaran formal tentang ketentuan-ketentuan sintaksis.

Semantik (semantics) mengacu pada makna kata dan kalimat. Setiap kata memiliki seperangkat gambaran semantik. misalnya girl dan woman, berbagi gambaran semantik yang sama dengan kata female dan human, tetapi berbeda dengan hubungannya dengan usia.

Pragmatik (pragmatics) yaitu kemampuan untuk melibatkan diri dalam percakapan yang sesuai dengan maksud dan keinginan. Ketentuan-ketentuan pragmatics tertentu menjamin bahwa suatu kalimat tertentu akan diucapkan di dalam suatu konteks tertentu dan tidak pada konteks lain. Melalui pragmatik kita belajar menyampaikan makna yang dimaksudkan dengan kata-kata, 
ungkapan, dan kalimat. Pragmatik menolong kita berkomunikasi secara lebih lancar dengan orang lain.

Teori yang sering digunakan dalam perkembangan psikologi, yakni teori Piaget dan Vygotsky. Kedua teori ini dapat memberi informasi penting bagaimana anak sebagai siswa yang sedang belajar bahasa terutama bahasa asing. Menurut Piaget, anak merupakan pembelajar dan pemikir aktif. Anak-anak akan selalu berinteraksi secara terus menerus dengan lingkungan sosialnya dan memecahkan permasalahan yang sedang anak hadapi di lingkungannya tersebut, sehingga proses belajar terjadi secara aktif. Hal ini dihasilkan oleh anak sendiri, bukan dari hasil menirukan orang lain. Piaget menyatakan bahwa anakanak akan selalu berusaha mencari pengertian mengenai lingkungan di sekitarnya dengan bertanya karena mereka ingin mengetahui lingkungan di sekitarnya. Juga sejak usia dini, anak selalu mempunyai maksud dan tujuan tertentu dalam setiap hal yang ia tanyakan atau lakukan.

Piaget (dalam Mukhlisah, 2015) membagi skema yang digunakan anak untuk memahami dunianya melalui empat periode utama yang berkorelasi dengan dan semakin canggih seiring pertambahan usia, yaitu: sensorimotor, praoperasi, operasi konkret, dan operasi formal. Dia percaya bahwa semua anak melewati tahap-tahap tersebut dalam urutan seperti ini dan bahwa tidak seorang anak pun dapat melompati satu tahap, walaupun anakanak yang berbeda melewati tahap-tahap tersebut dengan kecepatan yang agak berbeda.
Berikut adalah tabel ringkasan tahaptahap perkembangan kognisi menurut Piaget:

Tabel 1

Tahapan perkembangan Kognisi Piaget

\begin{tabular}{|c|c|c|}
\hline Tahap & Usia & Pencapaian Utama \\
\hline Sensorimotor & $\begin{array}{l}0-2 \\
\text { tahun }\end{array}$ & $\begin{array}{l}\text { Pembentukan konsep } \\
\text { "keajekan objek dan } \\
\text { kemajuan bertahapa } \\
\text { dari perilaku refleks ke } \\
\text { perilaku yang di } \\
\text { arahkan oleh tujuan. }\end{array}$ \\
\hline Praoperasional & $\begin{array}{l}2 \quad-7 \\
\text { tahun }\end{array}$ & $\begin{array}{l}\text { Perkembangan } \\
\text { kemampuan } \\
\text { menggunakan simbol } \\
\text { untuk melambangkan } \\
\text { objek di dunia ini. } \\
\text { Pemikiran masih terus } \\
\text { bersifat egosentris dan } \\
\text { Terpusat }\end{array}$ \\
\hline $\begin{array}{l}\text { Operasional } \\
\text { Konkret }\end{array}$ & $\begin{array}{l}7-11 \\
\text { tahun }\end{array}$ & $\begin{array}{l}\text { Perbaikan kemampuan } \\
\text { berpikir logis. } \\
\text { Kemampuan baru } \\
\text { meliputi penggunaan } \\
\text { pengoperasian yang } \\
\text { dapat dibalik. } \\
\text { Pemikiran } \\
\text { tidak terpusat, dan } \\
\text { pemecahan masalah } \\
\text { kurang oleh } \\
\text { dibatasi } \\
\text { egosentrisme. } \\
\text { Pemikiran abstrak } \\
\text { tidak mungkin. }\end{array}$ \\
\hline $\begin{array}{l}\text { Operasional } \\
\text { Format }\end{array}$ & $\begin{array}{l}11 \text { tahun - } \\
\text { dewasa }\end{array}$ & $\begin{array}{l}\text { Pemikiran abstrak dan } \\
\text { semata-mata simbolik } \\
\text { dimungkinkan. Masalah } \\
\text { dapat dipecahkan } \\
\text { melalui penggunaan } \\
\text { eksperimentasi } \\
\text { sistematik. }\end{array}$ \\
\hline
\end{tabular}

Anak yang berada di jenjang sekolah Taman Kanak-kanak (TK) berada di tahap pemikiran pra-operasional. Tahap ini berada pada rentang usia antara 2-7 tahun. Pada tahap ini anak mulai melukiskan dunia dengan katakata dan gambar-gambar atau simbol. Menurut Piaget, walaupun anak-anak pra sekolah dapat secara simbolis melukiskan dunia, namun mereka masih belum mampu untuk melaksanakan "Operation" (operasi), yaitu tindakan mental yang diinternalisasikan yang memungkinkan anak-anak melakukan secara mental yang sebelumnya dilakukan secara fisik.

Menurut Vygotsky (dalam Fakhruddin, 2015), berbeda dengan teori yang 
dikemukakan oleh Piaget tentang bahasa dan anak usia dini. Vygotsky berpendapat bahwa bahasa adalah faktor yang sangat penting bagi perkembangan anak usia dini. Melalui bahasa, Vygotsky meyakini bahwa seorang anak sedang menyerap pemahaman baru, atau bahkan nilai-nilai baru yang dianggapnya bermanfaa, minimal untuk dirinya sendiri.

Anak adalah bagian dari sosial. Pusat perkembangan dan belajar pada anak terjadi dalam konteks social. Konteks sosial itu adalah ketika anak berada di dunia yang penuh dengan orang lain, yang berhubungan dengan anak sejak lahir. Orang yang ada di lingkunga sekitarnya tersebut mempunyai peran yang cukup penting untuk menolong anak dalam proses belajar, melalui bermain dan permainan, mendongeng, berbicara, memperlihatkan benda dan ide-idenya, dll. Disini orang dewasa yang ada di lingkungan sekitanya adalah mediator dunia untuk anak-anak. Dengan bantuan orang dewasa yang ada di lingkungan sosialnya atau bantuan dari gurunya di sekolah, anak dapat mengerjakan dan memahami lebih banyak daripada mereka kerjakan dan pahami sendiri.

Hal ini berarti bahwa anak belajar untuk melakukan sesuatu dan belajar untuk berpikir, keduanya membutuhkan interaksi dengan orang dewasa yang ada di sekitar lingkungan sosialnya. Banyak dari teori Vygotsky ini yang dipakai untuk menyusun kerangka pengajaran bahasa asing untuk anak usia dini.

\section{Tabel 2}

\section{Penggunaan Bahasa Anak Usia Dini}

\begin{tabular}{|c|c|c|c|}
\hline $\begin{array}{c}\text { Usia } \\
\text { rata- } \\
\text { rata } \\
\text { (bulan) }\end{array}$ & $\begin{array}{c}\text { Panjang } \\
\text { pengucapan } \\
\text { (jumlah } \\
\text { rata-rata per } \\
\text { kalimat) } \\
\end{array}$ & Karakteristik & $\begin{array}{c}\text { Kalimat } \\
\text { yang } \\
\text { lazim } \\
\text { diucapk } \\
\text { an } \\
\end{array}$ \\
\hline $12-26$ & $1,00-2,00$ & $\begin{array}{l}\text { Perbendaharaann } \\
\text { kata utamanya } \\
\text { terdiri dari banyak } \\
\text { kata benda dan } \\
\text { kata kerja dengan } \\
\text { sedikit kata sifat } \\
\text { dan } \\
\text { keterangan; kata } \\
\text { urutan kata } \\
\text { diperhatikan } \\
\end{array}$ & $\begin{array}{l}\text { Bayi } \\
\text { mandi }\end{array}$ \\
\hline
\end{tabular}

\begin{tabular}{|c|c|c|c|}
\hline $27-30$ & $2,00-2,50$ & $\begin{array}{l}\text { Penggunaan kata } \\
\text { jamak; } \\
\text { menggunakan } \\
\text { past tense, } \\
\text { penggunaan be, } \\
\text { kata depan, } \\
\text { beberapa } \\
\text { preposisi }\end{array}$ & $\begin{array}{l}\text { Mobil } \\
\text { maju } \\
\text { cepat }\end{array}$ \\
\hline $31-34$ & $2,50-3,00$ & $\begin{array}{l}\text { Menggunakan } \\
\text { pertanyaan ya- } \\
\text { tidak, pertanyaan } \\
\text { wh (who, what, } \\
\text { where); } \\
\text { menggunakan } \\
\text { kalimat } \\
\text { sanggahan dan } \\
\text { kalimat berita }\end{array}$ & $\begin{array}{l}\text { Letakkan } \\
\text { bayi itu }\end{array}$ \\
\hline $35-40$ & $3,00-3,75$ & $\begin{array}{l}\text { Melekatkan } \\
\text { kalimat yang satu } \\
\text { di dalam kalimat } \\
\text { yang lain }\end{array}$ & $\begin{array}{l}\text { Ini } \\
\text { boneka } \\
\text { yang ibu } \\
\text { beli } \\
\text { untukku }\end{array}$ \\
\hline $41-46$ & $3,75-4,50$ & $\begin{array}{l}\text { Koordinasi antara } \\
\text { kalimat-kalimat } \\
\text { sederhana dan } \\
\text { hubungan- } \\
\text { hubungan } \\
\text { proposional }\end{array}$ & $\begin{array}{l}\text { Sinta dan } \\
\text { Andi itu } \\
\text { bersaudar } \\
\text { a }\end{array}$ \\
\hline
\end{tabular}

\section{METODE}

Pada penelitian ini, teknik pengumpulan data dilakukan dengan cara teknik wawancara. Teknik wawancara ini dilakukan untuk memperoleh informasi verbal secara langsung dari subyek penelitian. Wawancara dilakukan untuk mengetahui pengalaman-pengalaman dan sikap-sikap individu. Wawancara dilakukan dengan langsung bertemu dengan subyek penelitian. Selain wawancara, peneliti juga mengambil data tambahan dengan melakukan pendokumentasian media pembelajaran bahasa inggris yang ada beberapa sekolah tersebut.

Teknik analisis data yang digunakan dalam penelitian ini adalah teknik deskriptifkualitatif, yaitu teknik yang mencoba memberikan gambaran atau pemaparan atas subyek dan obyek penelitian sebagaimana hasil penelitian yang dilakukan kepada data yang berwujud kasus-kasus kualitatif, untuk kemudian dianalisis lebih lanjut seampai menjadi sebuah kesimpulan umum. 
Langkah-langkah dalam melakukan penelitian ini adalah:

1. Peneliti membuat rencana kerja. Rencana kerja adalah rencana kegiatan yang akan dilakukan selama penelitian, mulai dari membuat alat ukur sampai ke membuat hasil, kesimpulan, dan laporan penelitian. Penelitian dilakukan selama 6 bulan;

2. Peneliti merancang alat ukur yang akan digunakan untuk mengambil data dalam penelitian, berupa pertanyaanpertanyaan yang terkait dengan pembelajaran bahasa inggris pada anak usia dini yang diberikan para subyek (guru TK) ketika proses belajar mengajar di sekolah;

3. Peneliti menentukan sekolah Taman Kanak-kanak (TK) yang akan digunakan sebagai tempat penelitian di kecamatan Sukolilo kota Surabaya. Taman Kanakkanak (TK) yang digunakan sebagai tempat penelitian adalah Taman Kanakkanak (TK) yang menggunakan bahasa inggris di dalam proses belajar mengajar;

4. Pengambilan data dengan melakukan wawancara kepada subyek penelitian, yaitu guru Taman Kanak-kanak (TK) di Kecamatan Sukolilo Kota Surabaya. Wawancara dilakukan dengan memberikan pertanyaan-pertanyaan terkait pembelajaran bahasa inggris yang diberikan para subyek (guru TK) kepada siswa selama proses belajar mengajar. Selain itu peneliti juga mengumpulkan data pendukung dengan melakukan metode dokumentasi;

5. Melakukan pengolahan data penelitian. Data penelitian yang berhasil diambil adalah berupa hasil wawancara kepada guru Taman Kanak-kanak (TK) di Kecamatan Sukolilo Kota Surabaya terkait pembelajaran bahasa inggris yang digunakan subyek penelitian (guru TK) selama proses belajar mengajar di sekolah;

6. Melakukan analisis data penelitian. Analisis data penelitian dilakukan dari hasil pengolahan data yang telah dilakukan peneliti, yaitu hasil wawancara dengan guru Taman Kanakkanak (TK) di Kecamatan Sukolilo Kota Surabaya terkait pembelajaran bahasa inggris yang digunakan subyek penelitian (guru TK) selama proses belajar mengajar di sekolah.

\section{HASIL DAN PEMBAHASAN}

Penelitian ini merupakan kegiatan ilmiah yang berupaya memperoleh pengetahuan mengenai Pendidikan Anak Usia Dini khususnya di jenjang Taman Kanakkanak yang berkaitan dengan pembelajaran Bahasa Inggris yang dilakukan guru Taman Kanak-kanak (TK) di kecamatan Sukolilo Kota Surabaya. Dari jumlah total 57 Taman Kanakkanak (TK) yang ada di kecamatan Sukolilo kota Surabaya, terdapat 28 Taman Kanakkanak (TK) yang menjadi tempat penelitian. Dari data yang didapat oleh peneliti, sebanyak 28 Taman Kanak-kanak (TK) yang menjadi subyek penelitian telah memberikan pembelajaran bahasa inggris selama proses belajar mengajar.

Hasil wawancara, hampir semua Taman Kanak-kanak (TK) menggunakan berbagai macam metode pembelajaran bahasa inggris. Metode pembelajaran yang banyak digunakan guru Taman Kanak-kanak di kecamatan Sukolilo kota Surabaya untuk bahasa inggris adalah gerak dan lagu. Sebanyak 36\% dari subyek yang dilakukan wawancara, menggunakan metode gerak dan lagu dalam pembelajaran bahasa inggris di Taman Kanak-kanak (TK). Selain itu, para guru tersebut juga menggunakan metode permainan, bercerita, bermain peran, dan seni dan kerajinan tangan sebagai metode 
pembelajaran bahasa inggris di Taman Kanakkanak (TK).

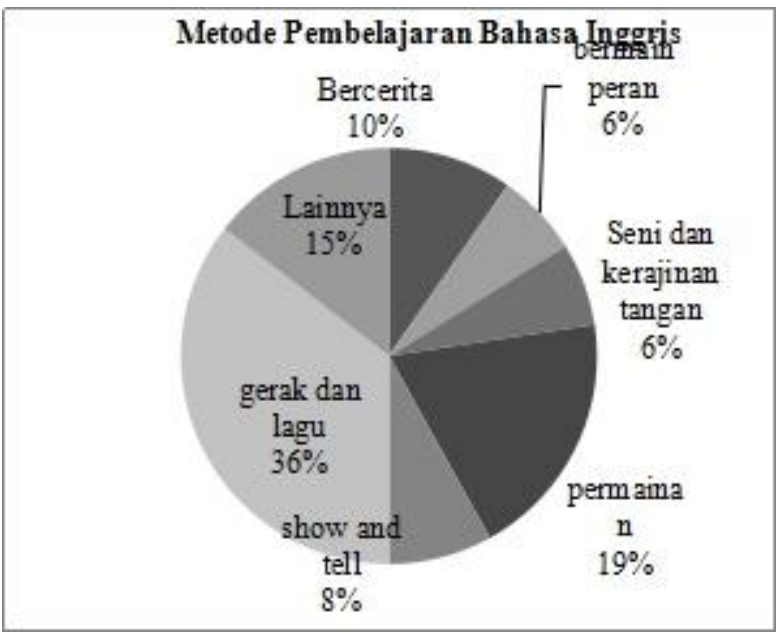

Gambar 1

Metode Pembelajaran Bahasa Inggris di

Taman Kanak-Kanak Kecamatan Sukolilo Kota Surabaya

\section{Pembahasan}

Bahasa bahkan dipandang sebagai penolong anak dalam memikirkan aktivitas yang sedang dilakukan orang-orang di sekitarnya, dan bagaimana ia seharusnya juga beraktivitas. Vygotsky sendiri menganggap bahasa sebagai cara anak untuk menelan konsepsi tentang bagaimana memerhatikan sesuatu, menghafalkan kembali apa yang didapat, memberikan kategorisasi, merencanakan, memecahkan masalah, dan memikirkan dunia anak (diri-pribadi) sendiri (dalam Fakhruddin, 2015).

Perkembangan bahasa anak sebenarnya sudah dimulai sejak anak lahir dengan menggunakan bahasa atau prabicara yang paling sederhana yaitu "menangis", kemudian

perkembangan dalam bentuk "celoteh/ocehan", kata/ kalimat sederhana disertai gerakan tubuh/ syarat sebagai pelengkap bicara. Anak menggunakan suara atau bahasa sebagai representasi benda atau kejadian. Melalui bahasa anak dapat berkomunikasi dengan orang lain tentang peristiwa kepada orang lain (Piaget, dalam Mukhlisah, 2015).

Bahasa Inggris mempunyai peran penting dalam proses pendidikan dan pembelajaran baik di sekolah maupun di rumah. Dalam pembelajaran bahasa inggris membutuhkan metode pembelajaran yang tepat untuk meningkatkan minat dan keinginan siswa dalam menggunakan bahasa inggris dalam aktifitas belajar yang menyenangkan dan diminati siswa. Pembelajaran bahasa Inggris yang diberikan kepada siswa mempunyai tujuan, yaitu agar siswa dapat berkomunikasi dengan menggunakan bahasa Inggris secara lisan maupun tulisan secara lancar dan sesuai dengan konteks sosialnya (Depdiknas, 2003). Kompetensi bahasa Inggris siswa mencakup keterampilan: mendengar, membaca, berbicara, dan menulis. Dalam Pendidikan Anak Usia Dini (PAUD), aspek yang dikembangkan adalah aspek pengembangan perilaku yang dilakukan melalui pembiasaan yang meliputi sosial, emosi, kemandirian, nilai-nilai moral dan agama serta pengembangan kemampuan dasar yang meliputi pengembangan fisik motorik, kognitif, dan bahasa (Arikunto, 2007).

Bahasa yang dipergunakan oleh anak adalah bahasa yang telah dimiliki dari hasil pengolahan dan telah berkembang. Selain itu, perkembangan bahasa anak juga dipengaruhi oleh lingkungan masyarakat dimana mereka tinggal. Hal ini berarti proses pembentukan kepribadian yang dihasilkan dari pergaulan dengan masyarakat akan memberi ciri khusus dalam penggunaan bahasa. Bersamaan dengan kehidupannya dalam masyarakat luas, anak mengikuti proses belajar di sekolah (Susanto, 2011).

Teori-teori Second Language Acquisition terbaru menyebutkan bahwa semakin dini anak belajar bahasa asing, semakin cepat mereka menguasainya karena alasan kemampuan short andlong term memory yang lebih baik. Disebutkan pula tekanan psikologis yang lebih sedikit dan 
faktor interaksi yang intens sangat disarankan untuk membantu anak-anak belajar bahasa asing. Di satu sisi, pembelajaran Bahasa Inggris pada anak pra-TK atau TK ini sangat menggembirakan, tetapi di sisi lain ada muncul juga kekhawatiran karena disinyalir masih terdapat banyak kekurangan dalam hal metode dan materi yang sesuai. Terlebih lagi secara teknis, dalam pelaksanaannya peranan guru dan kebijakan masing-masing sekolah menentukan bagaimana pembelajaran Bahasa Inggris sebagai bahasa asing untuk anak praTK atau TK tersebut terselenggara.

Dalam penelitian lain juga dinyatakan bahwa kebermanfaatan penguasaan bahasa asing lebih dini, memiliki kelebihan dalam hal intelektual yang fleksibel, keterampilan akademik, berbahasa dan sosial. Selain itu, anak tersebut cenderung memiliki kesiapan yang lebih matang ketika memasuki suatu konteks pergaulan dengan berbagai bahasa dan budaya. Sehingga ketika dewasa, anak akan menjadi sumber daya manusia yang berkualitas dan berprestasi. Pemahaman anak terhadap bahasa dan budayanya sendiri juga akan berkembang jika anak mempelajari bahasa asing sejak dini. Alasannya karena mereka akan memiliki akses yang lebih besar terhadap bahasa dan budaya asing. Akan tetapi, pembelajaran bahasa Inggris di Indonesia berbeda dengan pembelajaran bahasa Inggris sebagai bahasa kedua. Negaranegara di mana bahasa Inggris sebagai media komunikasi lebih mendukung secara lingkungan, karena anak dapat lebih mudah menemukan lingkungan yang menggunakan bahasa Inggris daripada di Indonesia.

Pada hakikatnya, anak-anak akan belajar bahasa asing dengan baik apabila proses belajar terjadi dalam konteks yang komunikatif dan bermakna bagi mereka. Untuk anak-anak konteks ini meliputi situasi social, cultural, permainan, nyanyian, dongeng dan pengalaman-pengalaman kesenian, kerajinan, dan olahraga. Salah satu metode pembelajaran yang digunakan guru Taman Kanak-kanak dalam bahasa inggris di Taman Kanak-kanak Kecamata Sukolilo Kota Surabaya adalah dengan menggunakan metode gerak dan lagu. Menurut Hidayat (dalam Miranti, dkk, 2015) lagu yang baik untuk anak usia Taman Kanak kanak adalah lagu yang memperhatikan beberapa hal sebagai berikut: kalimatnya pendek, mudah dihafal oleh anak-anak, ada misi pendidikan, sesuai karakteristik anakanak, dan nada yang dipakai mudah dikuasai anak. Selain itu, pembelajaran bahasa inggris sebaiknya dilakukan dengan tujuan pengenalan bahasa pada umumnya. Tujuan tersebut ialah supaya anak dapat memahami cara berbahasa

yang baik dan benar, berani mengungkapkan ide atau pendapatnya dan dapat berkomunikasi dengan lingkungannya.

Menurut Ela (2012) gerak dan lagu mempunyai peranan penting dalam proses tumbuh kembang anak. Musik mampu memberikan keseimbangan hidup bagi anak, manusia dapat mengungkapkan pikiran dan perasaan hatinya serta dapat mengendalikan aspek emosionalnya. Adapun nyanyian adalah bagian dari musik. Nyanyian berfungsi sebagai alat untuk mencurahkan pikiran dan perasaan untuk berkomunikasi dengan demikian bernyanyi merupakan kegiatan yang sangat disukai oleh anak-anak. Melalui metode bernyanyi diharapkan mampu menarik minat anak untuk melakukan kegiatan pembelajaran Bahasa Inggrisdengan senang dan tanpa beban. Dengan membuat anak menyukai metode pembelajaran yang digunakan, diharapkan proses pembelajaran berjalan dengan baik sehingga anak tidak merasa jenuh, bosan dan sulit untuk menguasai kosakata. Ketika anak sudah tertarik untuk melakukan pembelajaran dengan menggunakan metode bernyanyi maka anak akan mudah dalam mengikuti setiap tahapan pembelajaran maka anak akan mudah untuk menguasai dan menghafal kosakata bahasa Inggris (Miranti, dkk., 2015).

Kemampuan guru untuk menciptakan berbagai aktivitas belajar yang bisa berinteraksi dengan benda dan lingkungan 
sekitar mereka untuk meningkatkan pondasi berfikir, berbahasa, visi, dan perilaku mereka dan dapat mendorong kemauan siswa untuk belajar menjadi peranan penting dalam proses belajar mengajar (Widyasari, 2016).

Bahasa Inggris sebaiknya mulai diperkenalkan kepada anak sedini mungkin. Mengingat bahasa Inggris merupakan bahasa asing pertama di Indonesia, maka proses pembelajarannya harus dilakukan secara bertahap. Pemilihan materi yang sesuai dengan usia anak dan juga efektif untuk perkembangan kognitif bahasa anak serta situasi belajar yang menyenangkan haruslah menjadi perhatian utama dalam berhasilnya suatu proses pembelajaran. Keberhasilan proses pembelajaran bahasa Inggris pada anak usia dini tentunya dipengaruhi oleh banyak faktor, antara lain:

1. Guru yang berkualitas, guru yang dapat menghidupkan proses kegiatan belajar mengajar.

2. Sumber dan fasilitas pembelajaran yang memadai dan memenuhi syarat (adekuat).

3. Kurikulum yang baik, sederhana, dan menarik (atraktif).

\section{SIMPULAN}

Pembelajaran bahasa inggris diberikan oleh guru Taman Kanak-kanak di Kecamatan Sukolilo Kota Surabaya. Belajar bahasa Inggris pada anak-anak di Taman Kanak-kanak menjadi bahasan yang sangat menarik dan menantang. Di sisi lain ada juga kekhawatiran yang timbul karena masih banyak kekurangan dalam hal metode pembelajaran dan bahan ajar yang sesuai, yang dapat digunakan oleh para guru di sekolah. Apalagi secara teknis, dalam pelaksanaannya peran guru dan kebijakan masing-masing sekolah menentukan bagaimana bahasa Inggris yang digunakan sebagai bahasa asing yang dipelajari oleh siswa taman kanak-kanak. Penggunaan metode pembelajaran pada Anak Usia Dini juga berperan penting dalam penyampaian materi bahasa Inggris. Metode yang dapat digunakan guru dalam memberikan materi pelajaran kepada Anak Usia Dini seperti bercerita, bernyanyi, bermain peran, dan lain-lain.

\section{DAFTAR PUSTAKA}

Arikunto, S. 2007. Manajemen penelitian. Jakarta: Rineka Cipta

Depdiknas. 2003. Undang-Undang RepublikIndonesia Nomor 20 Tahun 2003 tentang Sistem Pendidikan Nasional. Jakarta: Depdagri.

Ela, N. 2012. Peningkatan Penguasaan Kosa Kata Anak Usia Dini Melalui Aktivitas Gerak dan lagu. Upi Bandung. Skripsi. Tidak Diterbitkan. Online (Repository.upi.edu)

Fakhruddin, A., U. 2015. Teori Sosikultural Vygotsky (Pendekatan dalam Pendidikan Anak Usia Dini. Majalah Ilmiah Pawiyatan Edisi Khusus, Vol. XXII, (2) Juli.

Miranti, I., dkk. 2015. Penggunaan Media Lagu Anak-anak dalam Mengembangkan Kemampuan Kosakata Bahasa Inggis Siswa di PAUD. Faktor Jurnal Ilmiah Pendidikan, Vol. II (2) Juli.

Mukhlisah, A., M. 2015. Pengembangan Kognitif Jean Piaget dan Peningkatan Belajar Anak Diskalkulia. Jurnal Kependidikan Islam, Vol. 6 (2).

Santrock, J., W. 2004. Child Development tenth edition. New York: McGraw Hill Companies.

Sulistyo, G., H. 2009. Pembelajaran Bilingual pada Pendidikan Anak Usia Dini. Jurnal 
Kajian Teori dan Praktik Kependidikan, Vol.36 halaman 1-82.

Susanto, A. 2011. Perkembangan Anak Usia

Dini: Pengantar dalam Berbagai Aspeknya. Jakarta: Penerbit Kencana

Widyasari, F., E. 2016. Pembelajaran Bahasa Inggris dengan Menggunakan Metode Multiple Intelligences: Studi Kasus di Sekolah Internasional. Jurnal Edutama, Vol. 3 (1) Januari 2016. 